\title{
Cervical ectopic pregnancy: a rare case report
}

\section{Indu Verma*, Charvi Chugh, Unmesh Santpur, Pratibha Pundhir}

Department of Obstetrics and Gynecology, Maharishi Markandeshwar Institute of Medical Sciences and Research, Mullana, Ambala, Haryana, India.

Received: 24 March 2018

Accepted: 01 May 2018

*Correspondence:

Dr. Indu Verma,

E-mail: drinduverma68@gmail.com

Copyright: () the author(s), publisher and licensee Medip Academy. This is an open-access article distributed under the terms of the Creative Commons Attribution Non-Commercial License, which permits unrestricted non-commercial use, distribution, and reproduction in any medium, provided the original work is properly cited.

\begin{abstract}
Cervical ectopic pregnancy is rare condition which occurs in less than $1 \%$ of all ectopic pregnancies. Early diagnosis is a key to successful management; delayed diagnosis can lead to significant morbidity and fertility loss of the mother. We present a case of woman who presented with vaginal bleeding and lower abdominal pain for 3 days following amenorrhea of $31 / 2$ months. Ultrasound examination done outside was suggestive of left tubal ectopic pregnancy whereas scan done at our hospital indicated either uterine rupture within intraperitoneal sac or a cervical ectopic pregnancy. She was taken up for laparotomy and hysterectomy since she was bleeding profusely, and it was lifesaving.
\end{abstract}

Keywords: Cervical ectopic pregnancy, Hysterectomy, Laprotomy, Ultrasound examination

\section{INTRODUCTION}

Ectopic pregnancy is defined as implantation of blastocyst in tissue other than the endometrial lining of the uterine cavity. Nearly $95 \%$ of ectopic pregnancies are implanted in the various segments of fallopian tube, most common site being the ampulla. ${ }^{1}$ In cervical ectopic pregnancy, the implantation occurs in endocervical canal which is a rare condition, accounting for less than $1 \%$ of ectopic pregnancies. ${ }^{2}$ Incidence varies from 1:8600 to $1: 12,400$ of total pregnancies. Nowadays due to improved ultrasound resolution (including transvaginal ultrasound) has made it possible for early detection of these pregnancies and lead to more conservative treatment with an attempt to limit morbidity and preserve fertility. Common risk factors for cervical pregnancy are prior dilatation and curettage, prior caesarean section and in vitro fertilization. ${ }^{3}$

The most common symptom is vaginal bleeding usually painless, following a period of amenorrhea. Sometimes vaginal bleeding is massive which may necessitate hysterectomy.

\section{CASE REPORT}

Thirty-three years old women presented with history of 3 months amenorrhea, bleeding per vaginum and pain lower abdomen since last 3 days. Her ultrasound done by referring doctor was suggestive of enlarged uterus, normal right fallopian tube in size and shape but enlarged left fallopian tube due to left ectopic pregnancy. Patient confirmed pregnancy by positive urine pregnancy test at 8 weeks of amenorrhea and urine for pregnancy test done at the time of admission was also positive.

She was an unbooked case with no history of any antenatal checkup. She had a cesarean section done two years back at Civil Hospital for transverse lie with history of secondary PPH. At that time, 21 days following caesarean section, dilatation and curettage was done for retained products of conception, a vaginal pack was inserted for 24 hours and later referred to our hospital for further management. Here she was examined under anaesthesia and was successfully managed with conservative treatment. In this pregnancy, on general physical examination in our hospital she was conscious, 
well oriented to time place and person, thin built and, had moderate pallor. She had a pulse of $114 / \mathrm{min}$ and blood pressure of $80 / 50 \mathrm{~mm} \mathrm{Hg}$. Immediately an intravenous access was established with $16 \mathrm{G}$ cannula and $1000 \mathrm{ml}$ of ringer lactate were infused. Blood sample was sent for routine investigations along with grouping and cross match. On examining the abdomen, a previous midline vertical infra umblical scar was present and uterus was 12 weeks size. On gynaecological examination with speculum her external os was closed and obvious continuous bleeding was present. On per vaginal examination her cervix was posterior, deviated to left side, enlarged with marked ballooning, uterus was soft, anteverted of 12 weeks size and deviated to right side.

Tenderness was also present. Ultrasound done at our institute revealed a gestational sac without overlying myometrium. Fetal pole measured about $5.3 \mathrm{~cm}$, corresponding to gestational age of about 12 weeks 0 days. Fetal Heart Rate was absent with degenerative cystic changes within placenta. These findings suggested either uterine rupture with intraperitoneal sac or a cervical ectopic pregnancy. Informed written consent was obtained for emergency exploratory laparotomy with possibility of hysterectomy and she was shifted to the operation theatre.

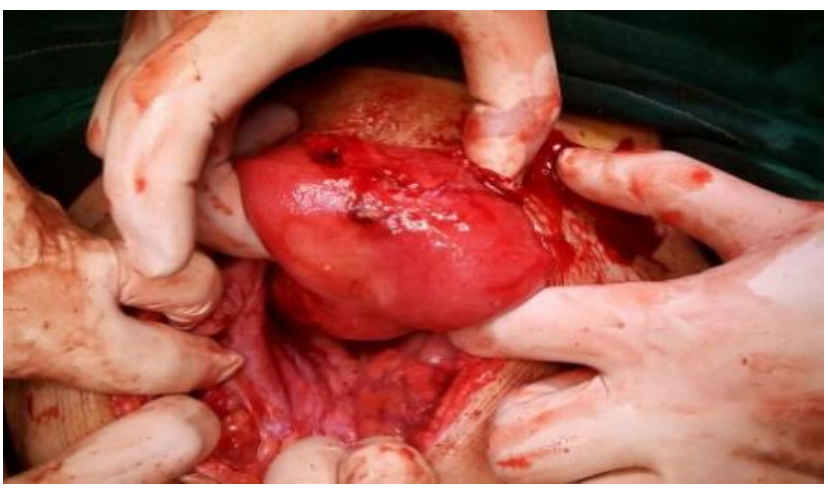

Figure 1: Intraoperative bicornuate uterus.

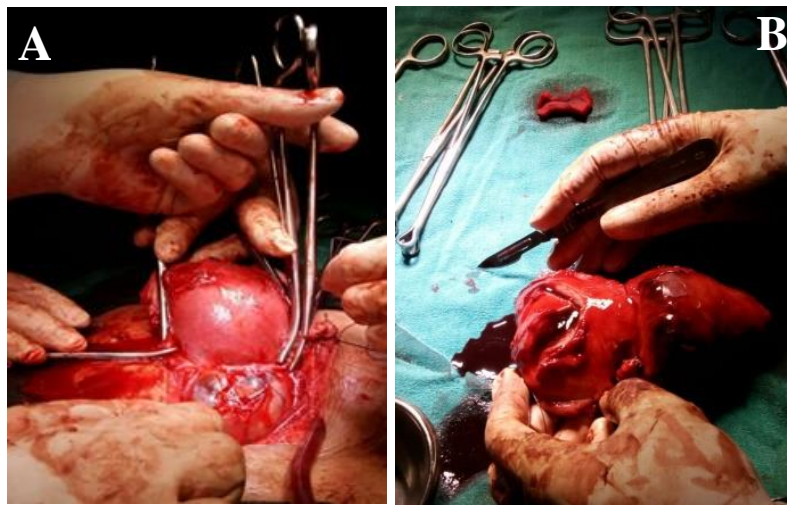

Figure 2: A) Intraoperative ballooned out cervix with thinning of wall. B) Figure 3: Hour glass uterus.

The abdomen was opened by a midline vertical infraumblical incision over the previous scar under general anaesthesia. Intraoperatively, dense adhesions were present between abdominal wall and the anterior uterine wall. Bilateral fallopian tubes and ovaries were normal, uterus was bulky and bicornuate (Figure 1), cervix was bluish in colour, distended, ballooned out measuring about $4 \times 5 \mathrm{~cm}$ (Figure 2'A) and the previous scar over the uterus was very thin.

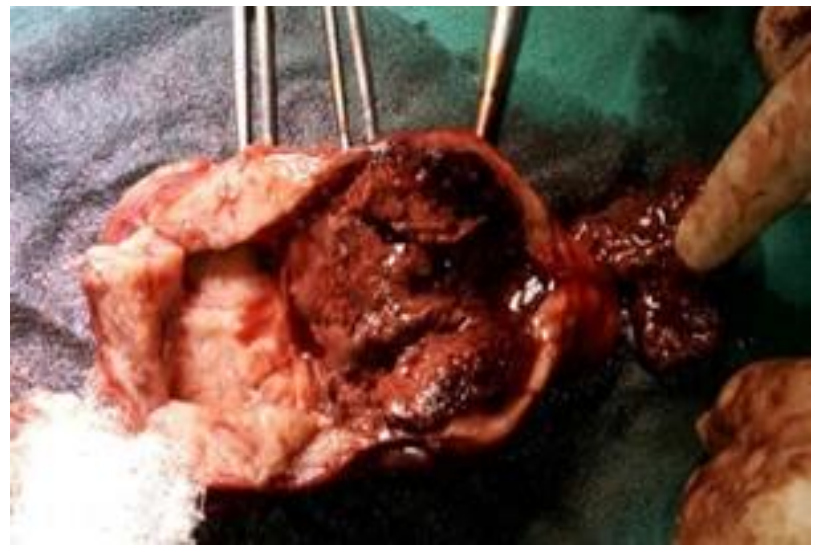

Figure 4: Products of conception implanted in the endocervix, empty uterine cavity and almost equal sized cervix and the uterus.

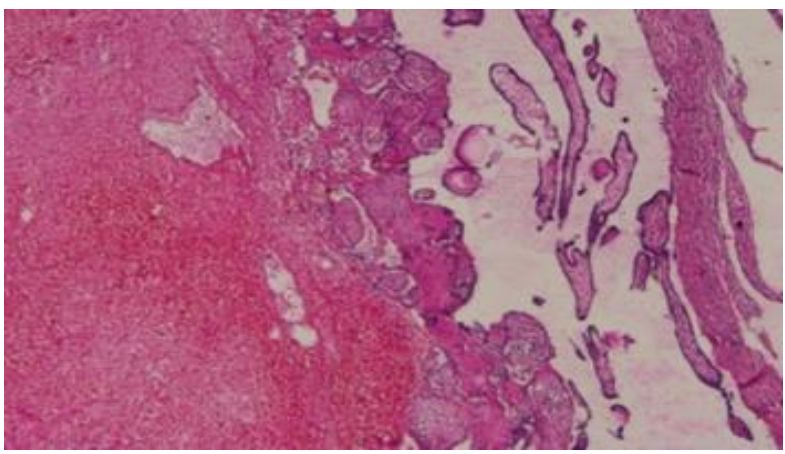

Figure 5: Histopathological examination of the tissue taken from the cervix showed cytotrophoblastic and syncytiotrophoblastic tissue along with fibrinoid necrosis and haemorrhage (H \& E 400x).

No haemoperitoneum was seen. Uterus along with the cervix was removed (Figure 3'B and 4) and sent for histopathology. The abdomen was closed in layers once heamostasis was ensured.

One unit whole blood was transfused intaoperatively and patient was put on injectable antibiotics and analgesics. Her entire post-operative period was uneventful, and she was discharged on tenth post-operative day.

\section{DISCUSSION}

Ectopic cervical pregnancy (CP) results due to implantation of fertilized ovum in the endocervical canal below the levels of internal os with a reported incidence of less than $0.01 \%$ of all pregnancies. Even with 
advanced diagnostic modalities and reduction in current maternal mortality rates, $\mathrm{CP}$ remains a life-threatening condition. ${ }^{4}$ Paalm and McElin in 1959 proposed five clinical practical criteria to diagnose cervical pregnancy which includes 5 :

- Uterine bleed without cramping pain following a period of amenorrhea.

- A soft, enlarged cervix equal to or larger than the fundus.

- Products of conception entirely confined within and firmly attached to endocervix.

- A close internal cervical os and

- A partially opened external cervical os.

\section{Rubins criteria for diagnosis of cervical pregnancy:}

- Cervical glands must be opposite the placental attachment.

- Placental attachment to the cervix muxt be situated below the entrance of the uterine vessels or below the entrance of uterine vessels or below the peritoneal reflection of anterior and posterior surface of the uterus,

- Fetal elements absent in uterus. ${ }^{6}$

\section{Ultrasonographic findings suggestive of cervical pregnancy are:}

- Hourglass uterine shaped and ballooned cervical canal

- Presence of gestational tissue in cervix

- Absent gestational tissue in the uterus

- Part of endocervical canal seen interposed between gestation and the endometrial canal.

In present case there was positive history of high risk factors for cervical pregnancy like previous dilatation and curettage and prior caesarean section. The clinical picture of present case suggesting cervical ectopic pregnancy were, uterine bleed following a period of amenorrhoea, a soft and enlarged ballooned out cervix almost equal in size to the uterine body.

Ultra sound report in present case was not conclusive as the outside report showed left tubal pregnancy. Author's pelvic examination suggested enlarged cervix pushed to the left side and uterus lying on the right side of the pelvis.

Repeat ultrasound suggested gestational sac without overlying myometrium suggestive of uterine rupture with intraperitoneal sac and absent foetal heart. Intraoperative finding showed bilateral normal tubes and ovaries with no haemoperitonium. Cervix was enlarged and ballooned with thinning of the cervical wall, cervix almost equal to the size of uterine body. Cut section of the specimen and histopathological examination confirmed the diagnosis of cervical pregnancy (Figure 5). Early and timely diagnosis is a key to successful management of the patient. Treatment options available are: Surgical intervention like laparotomy and hysterectomy which is done when patient is bleeding profusely and is lifesaving. Other options available are uterine artery embolization if the facilities are available, temponade with Foley's catheter, ligation of cervical branch of uterine artery, treatment with systemic and local methotrexate, sonographic guided potassium chloride in patients who develop cardiac activity, for patients desiring fertility and are stable. Cervical ectopic pregnancy must be differentiated from ongoing spontaneous abortion, cervical carcinoma, cervical or submucous leiomyoma, placenta previa and trophoblastic tumor. ${ }^{6}$

\section{ACKNOWLEDGMENTS}

Authors would like to thank Department of Pathology, Maharishi Markandeshwar Institute of Medical Sciences and Research, Mullana, Ambala.

Funding: No funding sources

Conflict of interest: None declared

Ethical approval: Not required

\section{REFERENCES}

1. Cunningham FG, Leveno KJ, Bloom SL, Spong CY, Dashe JS, Hoffman BL, et al. Ectopic Pregnancy. In: Cunningham FG, Kenneth J, Leveno, Steven L. Bloom, Spong CY, Dashe JS, Hoffman BL, Casey BM eds. Williams obstetrics $24^{\text {th }}$ ed. NewYork, NY: McGrawHill Medical;2014:377-395.

2. Celik C, Bala A, Acar A, Gezginc K, Akyurek C. Methotrexate for cervical pregnanacy- A case report. J Reprod Med. 2003;48:130-2.

3. Sharma A, Ojha R, Mondal S, Chattopadhyay S, Sengupta P. Cervical Intra-mural pregnancy: Report of a rare case. Niger Med J. 2013;54:271-3.

4. Mashiach S, Admon D, Oelsner G, Paz B, Achiron R, Zalel Y. Cervical Shirodkar cerclage may be the treatment modality of choice for cervical pregnancy. Hum Reprod. 2002;17:493-6.

5. Paalman RJ, McElin TW. Cervical pregnancy: a review of literature and presentation of cases. Am J Obstet Gynecol. 1959;77:1261-70.

6. Voedisch AJ, Frederick CE, Nicosia AF, Stovall TG, Berek JS, Novak E. Early Pregnancy Loss and Ectopic Pregnancy In: Berek JS, Berek DL eds. Berek \& Novak's Gynaecology $15^{\text {th }}$ ed. Philadelphia: Wolters Kluwer/ Lippincott Williams \&Wilkins;2012:619-51.

Cite this article as: Verma I, Chugh C, Santpur U, Pundhir P. Cervical ectopic pregnancy: a rare case report. Int J Reprod Contracept Obstet Gynecol 2018;7:2506-8. 